\title{
Drying parameters influence on 'Ameclyae' Opuntia ficus prickly pear oil quality
}

\author{
Hassini, L. ${ }^{\text {a*}}$; Desmorieux, H. ${ }^{\text {b }}$ \\ ${ }^{a}$ University of Tunis El Manar, Faculté des Sciences de Tunis. Laboratoire d'Energétique et des \\ Transferts Thermique et Massique (LETTM), El Manar, 2092, Tunis, Tunisia. \\ bUniversité Claude Bernard Lyon 1, Laboratoire d'Automatique et de Génie des Procédés (LAGEP), \\ UMR CNRS 5007, 69622 Villeurbanne, France.
}

*E-mail of the corresponding author: helene.desmorieux2@univ-lyon1.fr

\begin{abstract}
The aim of this work is to study the effects of drying conditions on the quality of extracted pricly pear seed oil, specifically $\alpha$-tocopherol content. Drying experiments were carried on following a full $2^{3}$ factorial design using a vertical drying tunnel. The temperature range was 45 to $70^{\circ} \mathrm{C}$, relative humidity range was $15-30 \%$ and air velocity was 1 and $2 \mathrm{~m} / \mathrm{s}$. The MidilliKucuk model was found with satisfaction describing the seed air drying curves with a correlation coefficient of 0.999 and a standard error of 0.01 . For each drying condition, the extraction of fixed oil seeds was performed at cold using mechanical pressing method. The oil quality was evaluated on the basis of the $\alpha$-tocopherol content. The $\alpha$-tocopherol was identified and quantified by high-performance liquid chromatography (HPLC-UV). According to the experimental results, it was found that convective drying of thin layer of seeds at soft air conditions, drying temperature of $45^{\circ} \mathrm{C}$, relative humidity of $15 \%$ and air velocity of $1 \mathrm{~m} / \mathrm{s}$ give the optimal quality of extracted oil in terms of $\alpha$-tocopherol content.
\end{abstract}

Keywords: prickly pear seeds; convective drying; semi-empirical modeling; $\alpha$-tocopherol seed oil; optimization. 


\section{Introduction}

The constantly research of new essential oil sources should be performed in order to meet the new needs of industry. Prickly pear cactus (Opuntia ficus-indica) is extensively cultivated in Tunisia. The current production is estimated at more than 1200000 tons of fruits per year.

Seeds constitute about $10-15 \%$ of the edible pulp and are usually discarded as waste after extraction of the pulp. According to Stintzing et al. ${ }^{[1]}$, oil processed from the seeds constitutes $7-15 \%$ of whole seed weight and is characterized by a high degree of instauration wherein linoleic acid is the major fatty acid (56.1-77\%). According to Hasani et al. ${ }^{[2]}$, the most active form of vitamin $\mathrm{E}$ in the oils seed is $\alpha$-tocopherol which is believed to protect the body against degenerative malfunction, particularly cancer and cardiovascular disease.

Fresh prickly pear seeds, by-products from prickly pear fruit processing, are highly perishable and their drying at equilibrium moisture content is recommended for the storage, standardization and the biochemical stability of the product before extraction ${ }^{[3]}$. According to the literature, convective drying affected the quantity and the quality of the extracted essential oil and volatile compounds from various medicinal and aromatic plants.

Therefore, this work aims (i) to investigate the effect of the hot-air convective drying conditions on the drying kinetics of a thin layer of prickly pear seeds, (ii) to select the best mathematical model predicting the drying curves (iii) to study, according to full $2^{3}$ factorial design approach, the effect of convective drying air conditions on the quality of fixed oil extracted from seeds, on the basis of the $\alpha$ tocopherol content, at temperature ranging from 45 to $70^{\circ} \mathrm{C}$, relative humidity between 15 and $30 \%$ and air velocity of 1 and $2 \mathrm{~m} / \mathrm{s}$.

\section{Materials and Methods}

Fruit samples of the 'Ameclyae' variety in the ripe stage (Fig.1) were harvested in August from Knais, region of Sousse (Tunisia). They were taken to the laboratory the same day, where they were carefully selected and washed with tap water to remove glochids and impurities. Then the fruits were air-dried during few minutes and manually peeled. Seeds were separated by pressing the whole edible pulp and rinsing the residue, several times abundantly with distilled water.

A laboratory scale convective dryer (designed and constructed in the LETTM laboratory) was used for realising drying tests of thin-layer of seeds. For each experiment, a mass of $500 \pm(1) \mathrm{g}$ of fresh prickly pear seeds was distributed on a stainless perforated tray as a thin layer of about $0.5 \mathrm{~cm}$ thickness. The tray was suspended to a digital balance, the balance being placed outside the drying chamber. The dryer worked in closed loop and was equipped with an industrial programmable controller to adjust air temperature, air relative humidity and air velocity to a given set point. The mass of the product was continuously measured and recorded by a microcomputer until constant weight. At the end of each 
drying test, the essential oil of the seeds was extracted and submitted to qualitative analyses. The dry mass of the product was determined by vacuum oven drying method at $105 \pm 1^{\circ} \mathrm{C}$ for 4 hours. The change in moisture of prickly pear seeds during drying was expressed as a moisture ratio MR defined by the expression of Eq. (1).

$$
M R=\frac{X-X_{e q}}{X_{o}-X_{e q}}
$$

where $\mathrm{X}, \mathrm{X}_{\mathrm{o}}$, and $\mathrm{X}_{\mathrm{eq}}$ are moisture content at any drying time, initial and equilibrium moisture content $\left(\mathrm{kg}\right.$ water/kg dry matter), respectively. This last parameter $\mathrm{X}_{\mathrm{eq}}$ was experimentally determined at different climatic conditions (desorption isotherms) ${ }^{[4]}$.
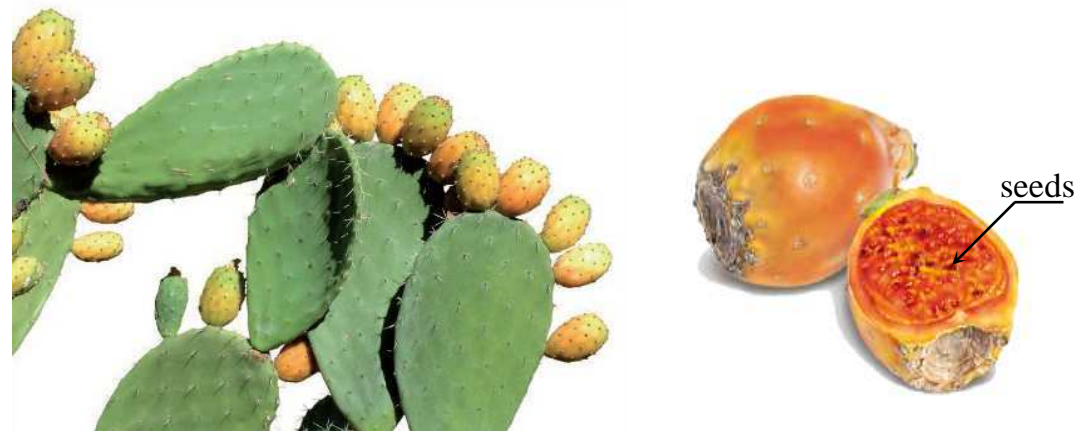

Fig. 1 Prickly pear fruit of the 'Ameclyae' variety.

The extraction of oil from dried seeds was performed at cold temperature using liquid/solid separation method. Before the extraction process, the dried seeds were reduced into a fine powder using electronic grinder, at a temperature around $23^{\circ} \mathrm{C}$. This mechanical separation processing is the most recommended in agricultural industry for its low cost and it preserves nutrients. There are four tocopherols and four tocotrienols in the seeds oil. $\alpha$-tocopherol was chosen because it is the most active molecule and represents a good reagent against oxidation parameters. Besides, the $\alpha$-tocopherol plays a vital role in the human body as antioxidant to neutralize free radicals and protect the cell tissues. The $\alpha$ tocopherol was identified and quantified by using an analytical HPLC system Agilent Series 1100 , equipped with a quaternary pump and a UV-visible detector (diode array detector). Identification of compound was achieved by comparing their retention time values with those of standard curve (concentration versus peak area).

\section{Results and discussion}

\subsection{Chromatograms of $\alpha$-tocopherol in prickly pear oil}

Typical chromatograms of $\alpha$-tocopherol in seeds oil corresponding to two different drying conditions are presented on Fig. 2. 


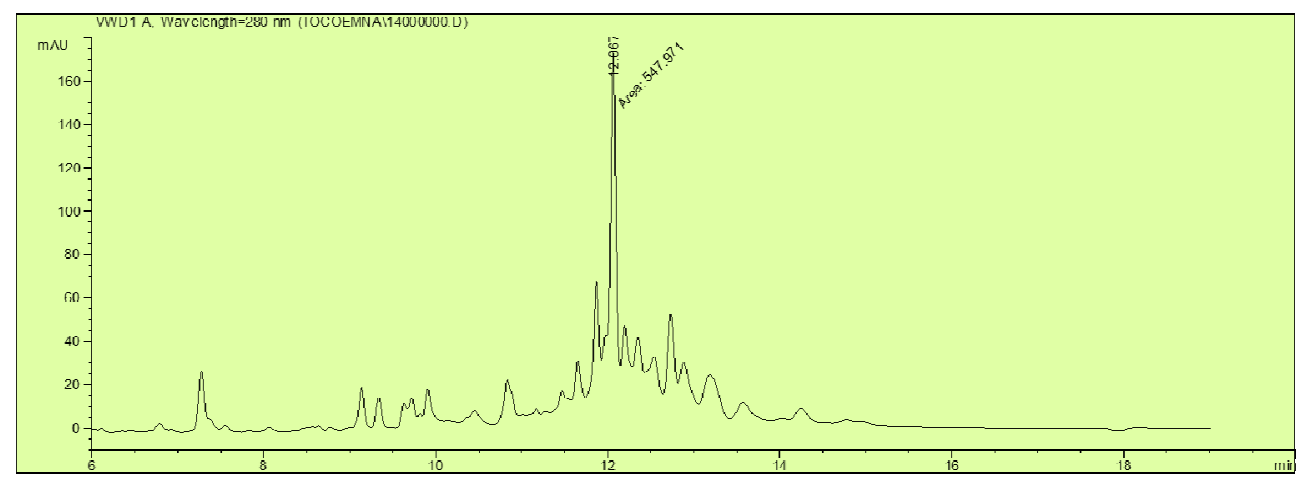

(a)

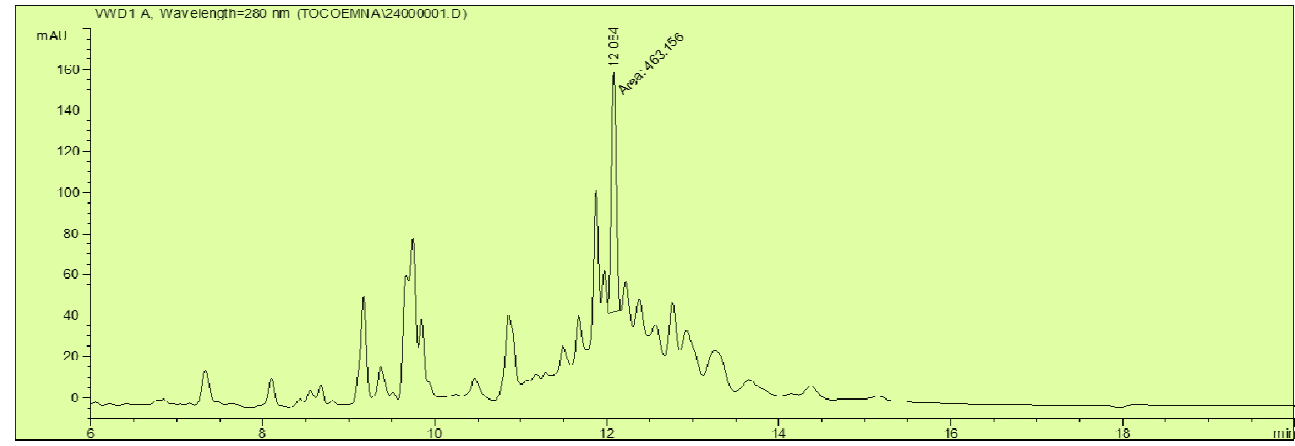

(b)

Fig. 2 Chromatograms of a-tocopherol in prickly pear oil (a) at $\left(T_{a}=70^{\circ} \mathrm{C}, \mathrm{HR}=15 \%, u_{a}=2 \mathrm{~m} / \mathrm{s}\right)$ and (b) at $\left(T_{a}=45^{\circ} \mathrm{C}, \mathrm{HR}=15 \%, u_{a}=2 \mathrm{~m} / \mathrm{s}\right)$

\subsection{Experimental drying curves}

The drying kinetics curves of thin layer prickly pear seeds at different drying conditions are given on Figs. 3 and 4. As it can be observed, the constant rate-drying period do not appear clearly in drying curves which is similar with those reported in literature: orange seeds by Rosa et al. ${ }^{[5]}$ and grapefruit seeds by Cantu-Lozano et al. ${ }^{[6]}$. The absence of a clearly constant rate period is due to the difficulty of the capillary migration of water from the wet heart to the rigid surfaces of prickly pear seeds. The heating up period is attributed to the warming of the seeds from the ambient temperature to the over temperature of 45 or $70^{\circ} \mathrm{C}$, and shorter by $45^{\circ} \mathrm{C}$ drying temperature. Otherwise, the air temperature is the operating parameter which affect significantly the drying kinetics of thin layer of seeds as reported by several investigators, e.g. Tang and Sokhansang ${ }^{[7]}$ for lentils and Desmorieux and Decaen ${ }^{[8]}$ for Spirulina. Although, the drying process is controlled by the water internal diffusion inside the seeds, the less important effect of air velocity on the drying kinetics can be explained by the dependence of the convective exchange coefficients with the air velocity. This suggests that the moisture content depends on the effective diffusion and can be simply modelled by the Fick's second law and the semi-empirical models derived from it. 


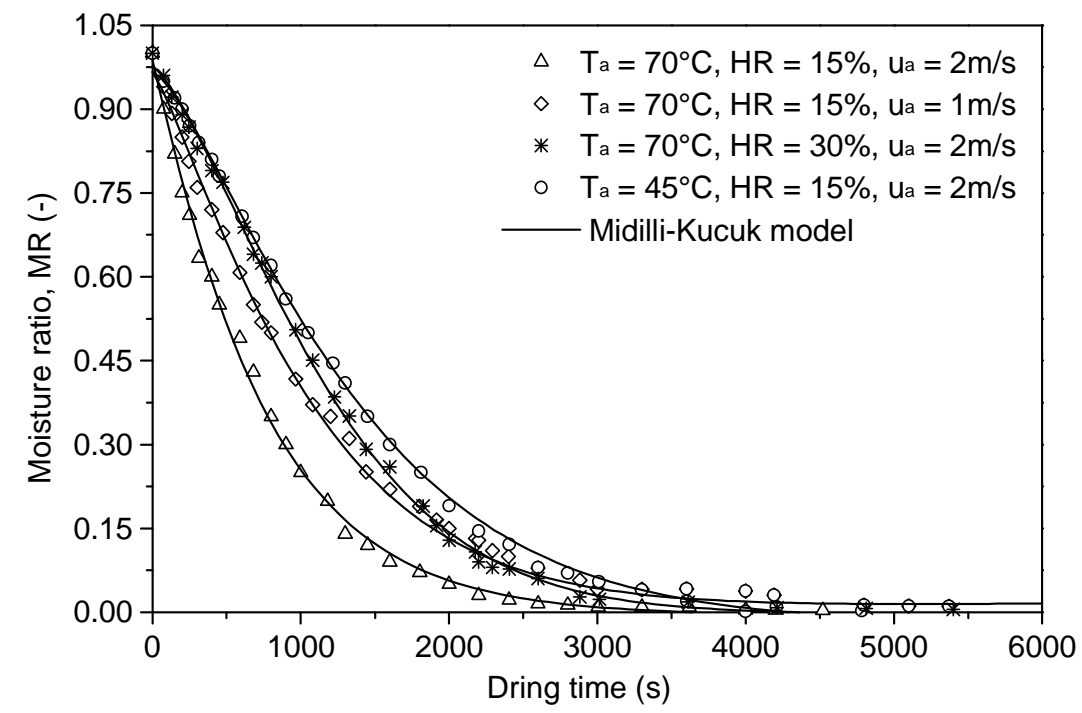

Fig. 3 Experimental prickly pear seeds moisture ratio versus

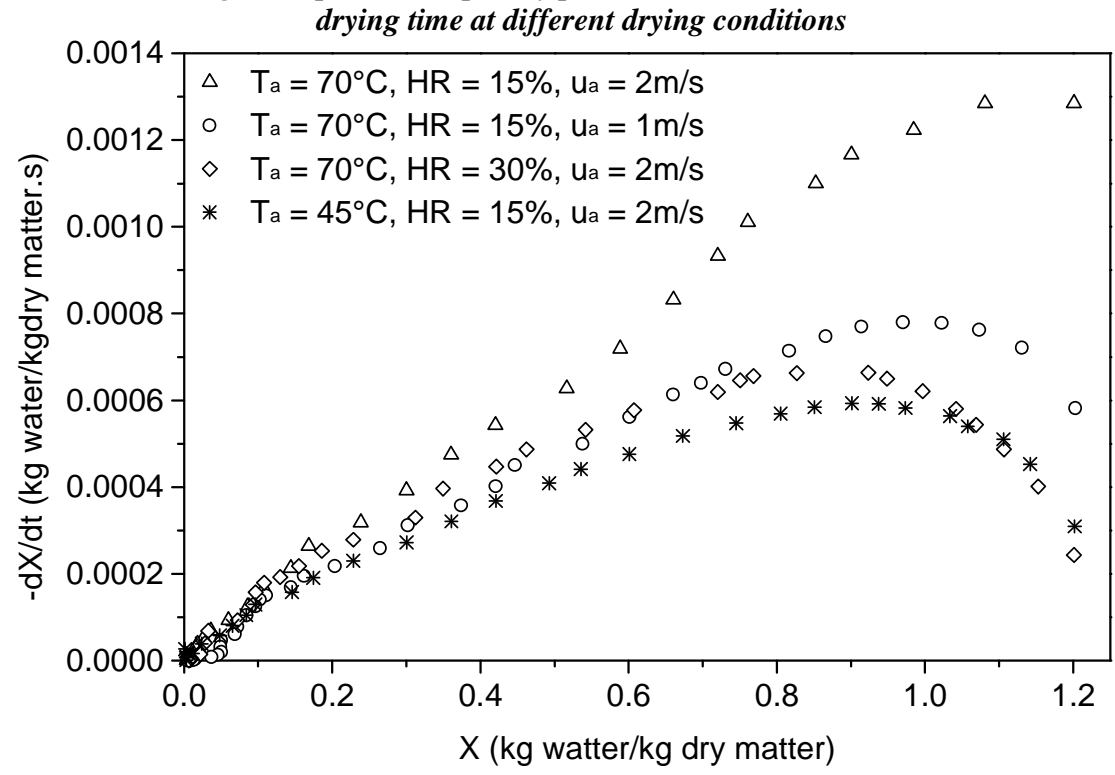

Fig. 4 Experimental drying rate versus moisture content at different drying conditions

\subsection{Smoothing of the experimental drying curves}

The experimental data obtained were fitted by eight semi-empirical models proposed in the litterature (Newton, Modified Page, Henderson and Babis, Modified Henderson and Pabis, Two-Term, Logarithmic and Midilli-Kucuk). All the models gave high coefficient of determination (r) values in the range 0.9697-0.9998 at $45{ }^{\circ} \mathrm{C}, 0.9615-0.9998$ at $50{ }^{\circ} \mathrm{C}$ and 
0.9474-0.998 at $70{ }^{\circ} \mathrm{C}$. This indicates that all the models could satisfactorily describe the convetive drying of the prickly pear seeds from 45 to $70^{\circ} \mathrm{C}$. According to our results, the Midilli-Kucuk model obtained the highest $r$ value of 0.9992 , and the lowest (s) value of 0.0143 , averaged over the range of the drying conditions. This selected Midili-Kucuk model is expressed as:

$$
\mathrm{MR}=\mathrm{n}_{1} \exp \left(\mathrm{kt}^{\mathrm{n}_{2}}\right)+\mathrm{n}_{3} \mathrm{t}
$$

\subsection{Effect of drying conditions on the extracted oil quality}

According to our results, reported in Table 1, $\alpha$-tocopherol was found in variable concentrations $(0.249-0.970 \mathrm{mg} / \mathrm{kg})$. These values are arithmetic mean of at least three separate determinations. They are lower than those reported by Ramadan and Morsel ${ }^{[9]}$ for prickly pear seed oils $(56 \mathrm{mg} / \mathrm{kg}$ ) obtained by solvent extraction and analyzed by HPLC technique. This difference in the $\alpha$-tocopherol concentration can be explained essentially by the fruit variety, the stage of fruit ripeness, the drying mode prior extraction and also the extraction process. Indeed, according to Tuberoso et al. ${ }^{[10]}$, tocopherol contents were significantly higher $(\mathrm{p}<0.05)$ in oils obtained by solvent extraction than by pressing. Furthermore, the amount of $\alpha$-tocopherol in grape seeds oil was $124,5 \mathrm{mg} / \mathrm{kg}^{[11]}$ and in Chia seed oil ranging from 0.4 to $9.9 \mathrm{mg} / \mathrm{kg}^{[12]}$.

Table 1. Q-tocopherol concentrations corresponding to $2^{3}$ factorial design

\begin{tabular}{ccccc}
\hline Test number & $\mathbf{T}_{\mathbf{a}}\left({ }^{\circ} \mathbf{C}\right)$ & $\mathbf{H R}(\%)$ & $\mathbf{u}_{\mathbf{a}}(\mathbf{m} / \mathbf{s})$ & $\mathbf{Y}(\mathbf{m g} / \mathbf{k g})$ \\
\hline 1 & 45 & 15 & 1 & 0.970 \\
2 & 70 & 15 & 1 & 0.830 \\
3 & 45 & 30 & 1 & 0.482 \\
4 & 70 & 30 & 1 & 0.491 \\
5 & 45 & 15 & 2 & 0.249 \\
6 & 70 & 15 & 2 & 0.463 \\
7 & 45 & 30 & 2 & 0.725 \\
8 & 70 & 30 & 2 & 0.311 \\
\hline
\end{tabular}

The effect of increasing the air velocity from 1 to $2 \mathrm{~m} / \mathrm{s}$, averaged over all levels of air temperature and air humidity, decreases the $\alpha$-tocopherol concentration from 0.693 to $0.437 \mathrm{mg} / \mathrm{kg}$. Also, the effect of increasing the air humidity from 15 to $30 \%$ decreases the $\alpha$-tocopherol concentration from 0.628 to $0.502 \mathrm{mg} / \mathrm{kg}$. Temperature is a factor of lesser 
importance. Indeed, the effect of increasing air temperature from 45 to $70^{\circ} \mathrm{C}$ decreases the $\alpha$-tocopherol concentration from 0.606 to $0.523 \mathrm{mg} / \mathrm{kg}$. That mean that $\alpha$-tocopherol molecule is more stable at heat treatments. Stability of $\alpha$-tocopherol is explained by the role of phenolic compounds that protect the $\alpha$-tocopherol from oxidation during the heating. Indeed, Ramadan and Morsel ${ }^{[9]}$ reported that, the amount of phenolic compounds in prickly pear seeds was found to be $403 \mathrm{mg} / \mathrm{kg}$ of seeds. According to Rocha et al. ${ }^{[13]}$, drying temperatures is the most important parameter to preserve the active ingredients of volatile oil in gland cells, which are very sensitive to temperature increase. Likewise, Miranda et al. ${ }^{[14]}$ observed an increase in tocopherol content with drying air temperature in quinoa seeds within temperature range of $40-80^{\circ} \mathrm{C}$. Our results show that $\alpha$-tocopherol is more sensitive to increase velocity, which can be linked to oxygen, than to the temperature. These results are consistent with those found by Park et al. ${ }^{[15]}$ who reported that more than $20 \% \alpha$-tocopherol degradation were observed in conditions of $21 \%$ oxygen.

\section{Conclusions}

- The experimental drying kinetics of a thin layer of prickly peer seeds exhibits a heatingup, constant rate and falling rate periods. The drying air temperature was the main factor influencing the drying kinetics.

- The Midilli-Kucuk model was the best for fitting the drying kinetics of prickly pear seeds.

- The relative humidity and the velocity of air were the factors that influence the prickly pear seed oil quality, qualified by $\alpha$-tocopherol contents after extraction. The convective drying of thin layer fresh seeds at air drying temperature of $45^{\circ} \mathrm{C}$, air relative humidity of $15 \%$ and air velocity of $1 \mathrm{~m} / \mathrm{s}$ involves the highest quality of extracted oil in terms of $\alpha$ tocopherol compound concentration. This optimum scenario for best oil quality can be used in photochemical industries.

\section{Nomenclature}

$\begin{array}{lll}\mathrm{HR} & \text { Air relative humidity } & (\%) \\ \mathrm{MR} & \text { Moisture ratio } & \\ \mathrm{T}_{\mathrm{a}} & \text { Air temperature } & \left({ }^{\circ} \mathrm{C}\right) \\ \mathrm{u}_{\mathrm{a}} & \text { Air velocity }(\mathrm{m} / \mathrm{s}) & \left(\mathrm{m} \cdot \mathrm{s}^{-1}\right) \\ \mathrm{X} & \text { Moisture content on dry basis } & \left(\mathrm{kg} \cdot \mathrm{kg}^{-1}\right) \\ \mathrm{Y} & \alpha \text {-tocopherol concentration } & \left(\mathrm{mg} \cdot \mathrm{kg}^{-1}\right)\end{array}$

\section{References}

[1] Stintzing, F.C.; Schieber, A.; Carle, R. Cactus pear, a promising component of functional food. Obst, Gemuse und Kartoffelverarbeitung 2000, 85(1), 40-47.

[2] Hasani, N.A.; Yussof, P.A.; Khalid, B.A.K.; Ghapor, M.T.A.; Ngah, W.Z.W. The possible mechanism of action of palm oil gamma-tocotrienol and alpha-tocopherol on 
the cervical carcinoma caski cell apoptosis. BioMed Research International 2008, 19, 194-200.

[3] Diaz-Maroto, M.C.; Pérez-Coello, M.S.; Gonzalez Vinas, M.A.; Cabezudo, M.D. Influence of drying on the flavor quality of spearmint (Mentha spicata L.). Journal of Agricultural and Food Chemistry 2003, 51, 1265-1269.

[4] Hassini, L.; Bettaieb, E.; Desmorieux, H.; Sandoval-Torres, S.; Touil, A. Desorption isotherms and thermodynamic properties of prickly pear seeds. Industrial Crops and Products 2015, 67, 457-465.

[5] Rosa, D.P.; Cantu-Lozano, D.; Luna-Solano, G.; Polachini, T.C.; Telis-Romero, J. Mathematical modeling of orange seeds drying kinetics. Ciênc Agrotec Lavras 2015, 39(3), 291-300.

[6] Cantu-Lozano, D.; Vigano, J.; Lassman, A.A.; Cantu, N.A.V.; Telis-Romero, J. Sorption isotherms and drying kinetics of grapefruit seeds. Acta Scientiarum 2013, 35(4), 717-723.

[7] Tang, J.; Sokhansanj, S. A model for thin-layer drying of lentils. Drying Technology 1994 12(4), 849-86.

[8] Desmorieux, H.; Decaen, N. Convective drying of spirulina in thin layer. Journal of Food Engineering 2015, 66, 497-503.

[9] Ramadan, M. F.; Môrsel, J-T. Oil cactus pear (Opuntia ficus-indica). Food Chemistry 2003, 82, 339-345.

[10] Tuberoso, I.G.C.; Kowalczyk, A.; Sarritzu, E.; Cabras, P. Determination of antioxidant compounds and antioxidant activity in commercial oilseeds for food use. Food Chemistry 2007, 103, 1494-1501.

[11] Bele, C.T.; Matea, C.; Raducu, C.; Miresan, V.; Negrea, O. Tocopherol Content in Vegetable. Oils Using a Rapid HPLC Fluorescence Detection Method. Notulae Botanicae Horti Agrobotanici Cluj-Napoca 2013, 41(1), 93-96.

[12] Bruscatto, M.H.; Zambiazi, R.C.; Sganzerla, M.; Pestana, V.R.; Otero, D.; Lima, R.; Paiva, F. Degradation of tocopherols in rice bran oil submitted to heating at different temperatures. Journal of Chromatographic Science 2009, 47, 762-765.

[13] Rocha, R.P.; Melo, E.C.; Radünz, L.L. Influence of drying process on the quality of medicinal plants: A review. Journal of Medicinal Plants Research 2011, 5(33), 70767084.

[14] Miranda, M.; Vega-Gálvez, A.; López, J.; Parada, G.; Sanders, M.; Aranda, M. Impact of air-drying temperature on nutritional properties, total phenolic content and antioxidant capacity of quinoa seeds (Chenopodium quinoa Willd.). Industrial Crops and Products 2010, 32, 258-263.

[15] Park, S. R.; Kim, Y. H.; Park, H. J.; Lee, Y. S. Stability of tocopherols and tocotrienols extracted from unsaponifiable fraction of rice bran under various temperature and oxygen condition. Proceedings of the 4th International Crop Science Congress, Brisbane, Australia, 2004. 